Meta

Journal des traducteurs

Translators' Journal

\title{
A Notional Approach to the Teaching of English Grammar
}

\section{Candace Séguinot}

Volume 28, numéro 3, septembre 1983

URI : https://id.erudit.org/iderudit/004080ar

DOI : https://doi.org/10.7202/004080ar

Aller au sommaire du numéro

Éditeur(s)

Les Presses de l'Université de Montréal

ISSN

0026-0452 (imprimé)

1492-1421 (numérique)

Découvrir la revue

Citer cette note

Séguinot, C. (1983). A Notional Approach to the Teaching of English Grammar. Meta, 28(3), 306-308. https://doi.org/10.7202/004080ar d'utilisation que vous pouvez consulter en ligne.

https://apropos.erudit.org/fr/usagers/politique-dutilisation/ 


\section{A NOTIONAL APPROACH TO THE TEACHING OF ENGLISH GRAMMAR*}

\section{Candace SÉGuinot}

A programme in translation confronts a student with at least two problems. The first is a mixture of theoretical and practical courses in which the link between the two is not always clear. In fact, the justification for suggesting that students take courses in linguistics or linguistic descriptions of particular languages is often expressed in terms of possible needs: some students may become interested in machine translation, for example. The second problem arises when students are asked to translate a variety of material from a second language into their mother tongue; they've never had to write much at all in their mother tongue, especially if they've majored in languages, and what they have written and are still writing, presumably, is academic French or academic English. Now they need to write business letters, advertisements, even poetry.

The solution to the second problem is easy. The training of translators has to include the teaching of writing and editing skills. This need has been recognized by the International Federation of Translators ${ }^{1}$ and it also crops up in articles written by teachers of translation ${ }^{2}$.

Member States should recognize in principle that translation is an independent discipline requiring an education distinct from exclusive

* Colloque de Glendon, 1980

1. The following is a recommendation by the Federation cited by $\mathrm{S}$. Congrat-Butlar, ed. in Translation and Translators, p. 57.

2. For example, Nancy Myers O'Connor (1979): "Translation as Re-Creation: An Experiment at Middlebury College", The French Review, LIII, 1, p. 64 language teaching and that this discipline requires special training. Member States should encourage the establishment of writing programs for translators, especially in connection with translators' professional organizations or associations, universities or other educational institutions, and the organization of seminars or workshops.

What I would like to suggest in this paper is that a particular kind of teaching of writing skills can also help solve the first problem, namely the gap between theoretical knowledge about language and the practical manipulation of the grammar of a particular language.

To better understand why one method of teaching writing differs from another, it might be a good idea to review some recent changes in the field. In the last ten years, the teaching of writing has taken on the connotation of a process of remediation. It has this connotation due to a general feeling that standards of writing have dropped, in both North American English and French. By the time the student has opted for higher education, however, it becomes more difficult to design a single course to cure all writing problems. There is also a lot of evidence to show that single courses don't help improve writing outside of that course anyway. What has developed therefore is a more individualized approach to writing; the development of writing clinics, labs, and workshops and the teaching of writing in courses with academic content.

The teaching of writing, like second language teaching, has also changed as the ultimate goal for both has shifted from the mastery of a set of specific skills to communicative competence. This shift is motivated by a particular philosophy of education which has received support from research into language learning, particularly 
research into natural, spontaneous learning of first and second languages. One of the findings of this kind of research has been that errors play an important role in language learning ${ }^{3}$. Not all errors are bad; some errors are proof that a student has actually improved. We see this kind of error in writing, for example, when a student overuses a complex syntactic construction which is in fact an improvement over previously simplistic style. And it is now clear that errors stem from different sources, a point which is particularly relevant in the teaching of translation.

Translation has traditionally been taught through the correction of errors in translation. Students are asked to do exercises which are designed to elicit the most predictable of these, and the actual teaching of translation takes place either as hints given before the exercise is attempted or as an explanation during the process of correction. This pedagogic strategy may lead to the use of exercises which were designed to catch errors of inattention as teaching tools and vice versa. In other words, translation exercises are often diagnostic in nature and the instructor has to judge the source of a given error. It is especially important in the teaching of writing that this judgement form an inherent part of the course, that performance errors be separated from and treated differently from errors based on a lack of knowledge or practice. Since exercises are primarily selected for difficulty in translation, it follows that the teaching of writing will be ad hoc to a certain extent if it is based on errors that come up in an exercise designed for a different purpose.

What is indicated, then, is an analysis of the writing needs of students of translation and a writing program which can be integrated into translation courses. Notional grammar, which is a theory of second language teaching, provides some helpful guidelines for the construction of a pedagogic syllabus, and I would like to suggest that these guidelines are also relevant for the development of a syllabus to teach writing skills.

The essence of this theory is that the selection of course content be based on an analysis of the items which are necessary to convey the notions - ideas or speech arts - which students will have to deal with when they leave the course $^{4}$. In a translation course we would assume that students have mastered the grammar of their second language at least to the extent that they are familiar with the grammatical units and their combinations. But if they have

3. S. Pit Corder (1967): "The Significance of Learner's Errors", IRAL, V, 4, p. 161-70

4. David Wilkins (1976) : Notional Syllabuses, Oxford, Oxford University Press, p. 19. had limited instruction in the functions of the various grammatical items, errors in writing as well as errors in translation may result. Let's take the use of the passive voice as an example of what might be taught in a syllabus on writing. Students will have learned the formation of the passive voice in their second language classes. Texts used in these classes generally treat the passive in a description of the verb system. If such a text is oriented toward translation, it may group the use of the passive with sources of possible interference, for example the problem of the faux passif in English. If students have taken a course in composition in their native or second languages, their knowledge of the uses of the passive voice depends on whether the approach used was traditional or functional. In older texts for the teaching of English composition it is not uncommon to see the passive listed as a prescribed form with an explanation that it is less effective than the active. A notional approach would look at the functions of the passive voice in the target and source languages and determine what uses a translator will make of these functions. The passive can be used to hedge statements, to change the focus of a text, to maintain objectivity and to mask ignorance. To preserve the original intentions of the $t \in x t$ and to write well, a translator has to be able to account for these functions in his or her translation.

If these functions are taught overtly we can avoid the traps of error-based teaching. This is especially relevant in the teaching of writing skills because the improvement of such skills is gradual, not immediate, and involves more than the avoidance of errors. Precisely because there is always room for improvement, some direct, non-error based teaching of writing will produce new skills not the least of which is the ability to edit one's own work and the work of others.

It might be useful here to stop and make a distinction between those parts of a translation program which involve language learning, where we can legitimately appropriate ideas from theories such as notional grammar, and those parts which do not. A part of any translation program is directed toward the furthering of the science, as opposed to the art or the craft, of translation. Now if we speak only about the furthering of skills of the latter kind, producing better translators rather than people who know about translation, or better writers, rather than people who know about writing, it follows that the learning of labels and definitions which are necessary as a part of the hypothesis - testing nature of science may not be useful. Here again we see the influence of the research into natural or first language learning which points out that learners can pass from ignorance to 
mastery of a language without going through as overt analysis of grammar. So a description of the kinds of items which contribute to good writing might look much like the items discussed in a course on discourse or textual analysis with the difference that labels would only be used when necessary. Because this kind of syllabus would be directed towards the pragmatic effect of variation, the presentation of items would be guided by functional rather than structural categories. This kind of approach is in some ways similar to theoretical courses which also focus on variation in and equivalence of meaning. In this respect, a notional approach to the teaching of writing can provide a meaningful link between courses in the theory of language and translation.

The notions that would be included in a given course on translation would depend on the purpose and intended audience of the writing for that course. Nevertheless, there are some basic notions that seem central to the production of controlled writing: continuity/discontinuity, focus, and emphasis. Students of translation need to understand, for example, that the language of advertising differs from the language of technical reports in much the same way that the language of literature does. These three aspects of writing are interrelated and rely on the manipulation of the same items and techniques: lexical items (prepositions, conjunctions and conjunctive adverbs), the placing of information in the subject or object position, initial and subsequent reference, repetition, parallel structure, and the use of the passive voice and impersonal constructions.

It's also helpful to know what makes a text "readable", formal or informal, complex and precise. These are areas where writing habits are often fixed. Both French and English speaking students, for example, naturally favour stative verbs with some kind of complement over the more forceful active. Another problem which frequently arises in student writing is the use of language too wordy or complex for the thought or the occasion. To combat this problem in a systematic way, a writer has to pay attention to the effects of separating grammatically dependant items an has to learn to tailor the use of modifiers to the purpose and audience of a text.

It's important for a translator to know that it's not only students who make these kinds of errors; it's the bulk of the people who write the texts he or she will probably be asked to translate. It's clear that translators have to deal with the intentions of an author, no just the text itself. An understanding of the means by which a text hangs together can help the translator separate cases of deliberate ambiguity and digression from those which are accidental.
This ability is becoming more valued as translators are called on to edit and simplify the writing of others. The trend to simplifcation in commercial and legal English has clearly begun, and soon translators in North America may find it necessary to prepare parallel texts in different styles. Such texts need to be annotated, so that a client can understand the effects of a given choice. A notional approach would provide the translator with a method for communicating with the client about the effect of different kinds of writing. To consider the example "He said to send a reply in no uncertain terms," there's no use asking the author whether he or she meant the adverbial phrase to be sentential or phrasal in scope!

A notional approach to the teaching of grammar can help build the bridge between the theory and the practice.

\section{BIBLIOGRAPHY}

CONGRAT-BUTLAR, S.,ed.(1979):Translation and Translators. An International Directory and Guide, New York and London, Bowker Co.

CORDER, S. Pit (1967): "The Significance of Learner's Errors', Iral, V, 4, p. 161-70.

O'CONNOR, Nancy Myers (1979) : "Translation as Re-Creation : An Experiment at Middlebury College', The French Review, LIII, 1, p. 60-67.

WILKINS, David (1972): "Grammatical, situational, and notional syllabuses', in A. VERDOODT, ed., Proceedings of the International Association of Applied Linguistics, Third Congress, Volume II, Applied Sociolinguistics, Heidelberg, Julius Groos Verlag, 1974, p. 254-265.

WILKINS, David (1976): Notional Syllabuses, Oxford, Oxford University Press. 